\section{The Use of Bovine Albumin in the Preparation of Marrow and Blood Films}

\author{
M. C. BERENBAUM \\ From the Department of Pathology, Chase Farm \\ Hospital, Enfield, Middlesex
}

(RECEIVED FOR PUBLICATION DECEMBER 27, 1955)

Most pathologists have experienced difficulty in preparing bone-marrow films after death. The maximum period in which this can be done is usually four hours after death, and films at all comparable with those obtained in life can only be made in the first hour (Rohr and Hafter, 1937; Jeanneret, 1940). Leitner (1949) says that results are valueless within half an hour of death. After this time the cell boundaries appear to dissolve more rapidly and the result of preparing films in the usual manner is a diffuse layer of cytoplasm in which bare cell nuclei are embedded, many of them ruptured.

A widespread impression exists that these changes are due to a peculiarly rapid autolysis taking place after death caused by "acidosis" or the liberation of proteolytic enzymes. However, routine paraffin sections of marrow obtained at necropsy reveal no more marked degeneration than is seen in other tissues. Accordingly it seemed likely that the unsatisfactory features of post-mortem films were due not to any special autolysis but simply to the inability of dead cells to resist the frictional and shearing forces involved in spreading films on glass. The following method was therefore devised, in which the cells are protected by suspension in a viscous medium.

\section{Method}

5\% Albumin Solution.-One part of Armour's 30\% bovine albumin is mixed with five parts of $0.85 \%$ saline.

Procedure.-Marrow was obtained from bodies stored in a mortuary refrigerator at $4^{\circ} \mathrm{C}$.

(1) From a rib or femur, a knife-point $(0.1-0.2 \mathrm{ml}$.) of marrow is scooped out and placed in 1-2 $\mathrm{ml}$. of $5 \%$ albumin.

(2) The marrow is broken up and mixed to make a fairly uniform suspension.

(3) The suspension is centrifuged and the pellicle of fat and most of the supernatant fluid drawn off. Supernate is left in the tube equal in volume to the deposit of marrow cells. It is important not to leave an excess of supernate. A 5:4 ratio of deposit to supernate is probably ideal.

(4) The deposit and remaining supernate are mixed by drawing up and down in a Pasteur pipette, drops are placed on slides, spread, dried, fixed, and stained in the usual way.
Notes.-For convenience the albumin solution may be dispensed in 1-2 ml. amounts in bijou bottles or small stoppered test-tubes and kept in the cold in the mortuary.

The marrow may be easily suspended by breaking it up between two swab-sticks ("orange sticks") rolled together between the finger and thumb in a 75 by $10 \mathrm{~mm}$. test-tube.

There is no urgency in preparing films once the marrow has been placed in the albumin solution, and the suspension may be kept for days in the refrigerator with little morphological change. In practice the marrow may be placed in a bijou-bottle of albumin solution during the necropsy, and preparation of films deferred till convenient.

In an infant, marrow may be obtained by breaking up the ossifying centre at the lower end of the femur with the sharp end of a metal spatula in a strong testtube or bottle containing albumin solution. The resulting turbid suspension is pipetted off and centrifuged.

A rapid modification of the method is to mix a fragment of marrow with a drop of $10-20 \%$ albumin on a slide before spreading. However, this is not so satisfactory, as the results are uneven, for, while some cells may be better shown than with the full method, others are excessively rounded up and unidentifiable.

\section{Results}

Changes in staining properties and morphology of marrow cells begin at death, but when this method is used such changes are slight, and highly satisfactory films may be made for the first $\mathbf{2 4}$ hours or so (Fig. 1). After 24 to 48 hours cell boundaries become increas-

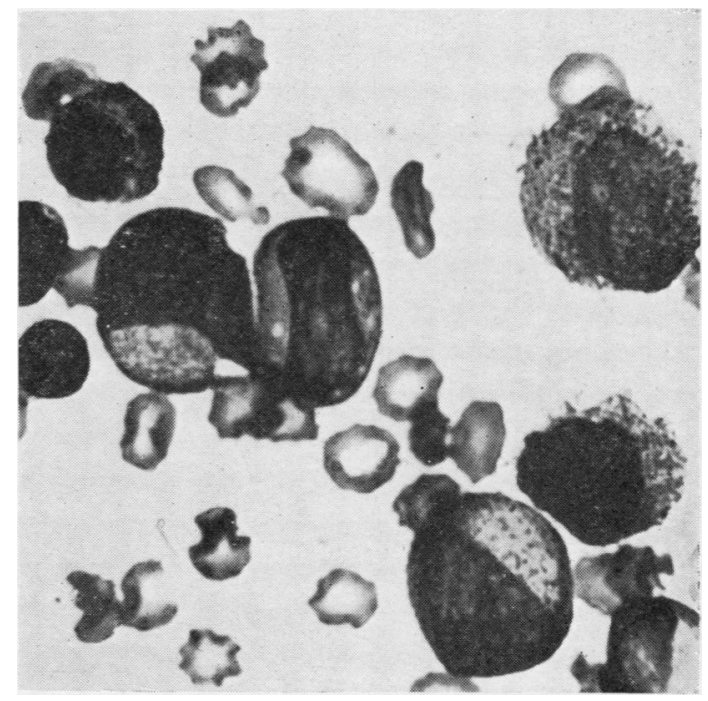

FIG. 1.-Marrow 48 hours after death (albumin method) showing ocy tes and metamyelocytes. Leishman, $\times 2,300$. 


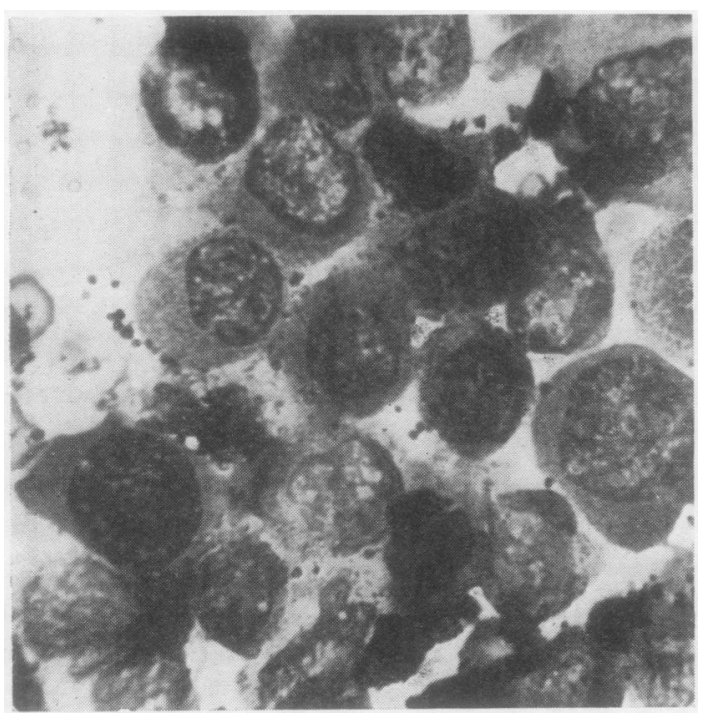

FIG. 2.-Marrow 68 hours after death (albumin method). Leishman, $\times 2,300$.

ingly frayed and cytoplasm and nuclei become increasingly vacuolated. However, even three or four days after death one can find many relatively intact normoblasts, myelocytes, megakaryocytes, plasma cells, and stromal cells (Fig. 2).

There is much variation betwen different subjects in the rate at which these changes occur, probably depending on the terminal illness (Jeanneret, 1940), and some subjects yield better specimens after 48 hours than others do at 24 hours.

\section{Further Applications}

The method may be used on marrow obtained during life, where it may give clinically useful information (Fig. 3a, b).

It may also be adapted to the study of peripheral blood, particularly in those cases of leukaemia where the majority of cells are disrupted when straightforward blood films are made. In this case, one part of $30 \%$ bovine albumin is mixed with five parts of heparinized venous blood, the mixture centrifuged and films made of the buffy coat (Fig. 4a, b).

Similar manœuvres may be used in examining cellular transudates or exudates or suspensions of splenic or lymph-node cells, where many cells are unduly fragile.

\section{Summary and Conclusions}

There would appear to be little basis for the theory that the marrow is subject to specially rapid autolysis after death and that this accounts for the changes seen in marrow films. In the method described here such changes are largely prevented by suspension of marrow in viscous medium. This enables the marrow to be examined up to four days after death, examination being most satisfactory in the first 24 hours.

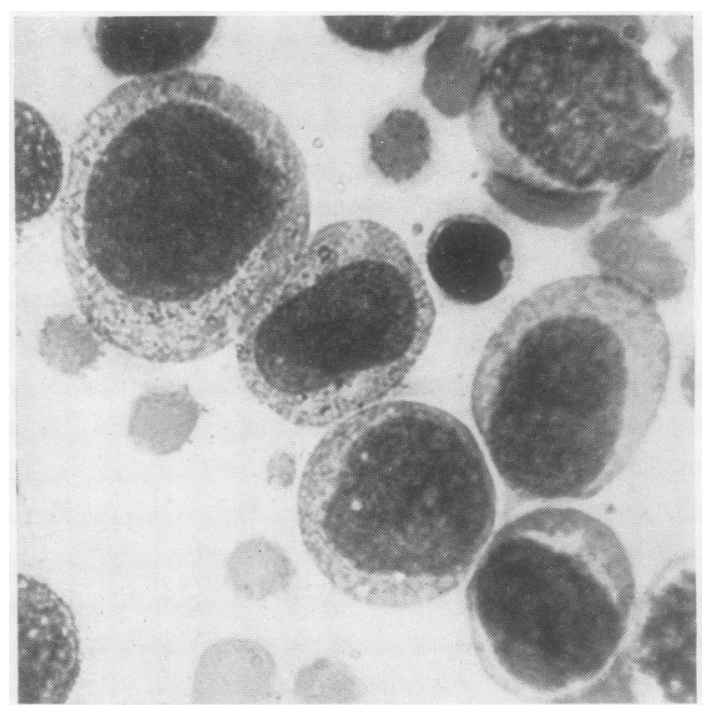

FIG. 3a.-Monocytic leukaemia, sternal puncture during life. All nuclei and cell boundaries are rounded and they do not show characteristic monocytic morphology. May-Grünwald-Giemsa, $\times 2,300$.

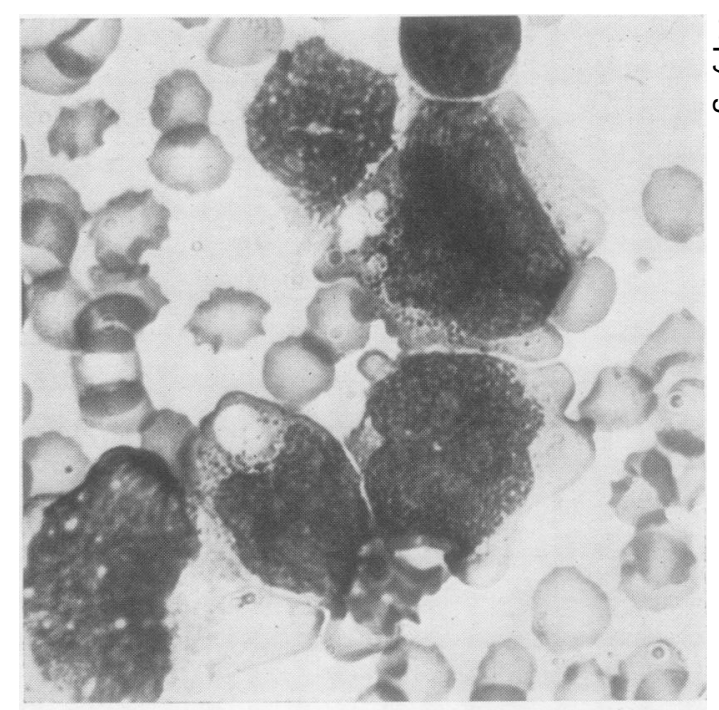

FIG. 3 b. - Same marrow, but prepared with $5 \%$ bovine albumin before spreading. The cells show definite monocytic features, including nuclear folding, pseudopodia and cytoplasmic vacuolation. The vacuoles were present but not so obvious in films made without albumin. May-Grünwald-Giemsa, × 2,300.

The method mav be applied with benefit to marrow obtained during life, to peripheral blood, and to cell suspensions of any kind.

I wish to thank Dr. H. Loewenthal, Senior Pathologist at Chase Farm Hospital, for his constant interest 


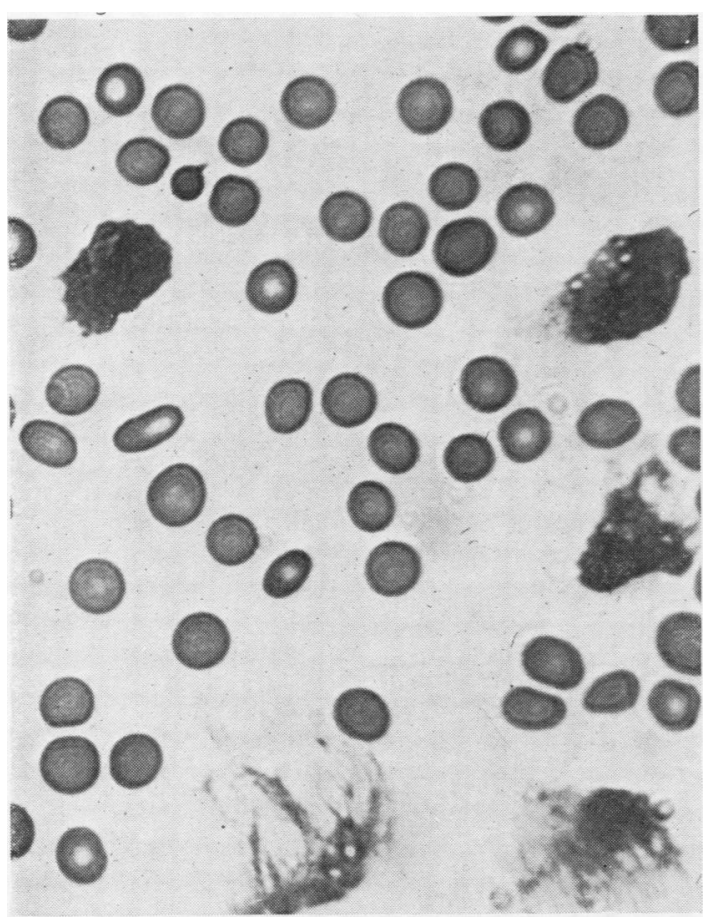

FIG. 4a.-Lymphatic leukaemia. Direct film from finger-prick The majority of cells are disrupted. Leishman, $\times 900$.

in this work, and Dr. M. C. G. Israëls, Dr. J. V. Dacie, and Dr. F. G. J. Hayhoe for advice. Mr. V. H. Knight took the photographs.

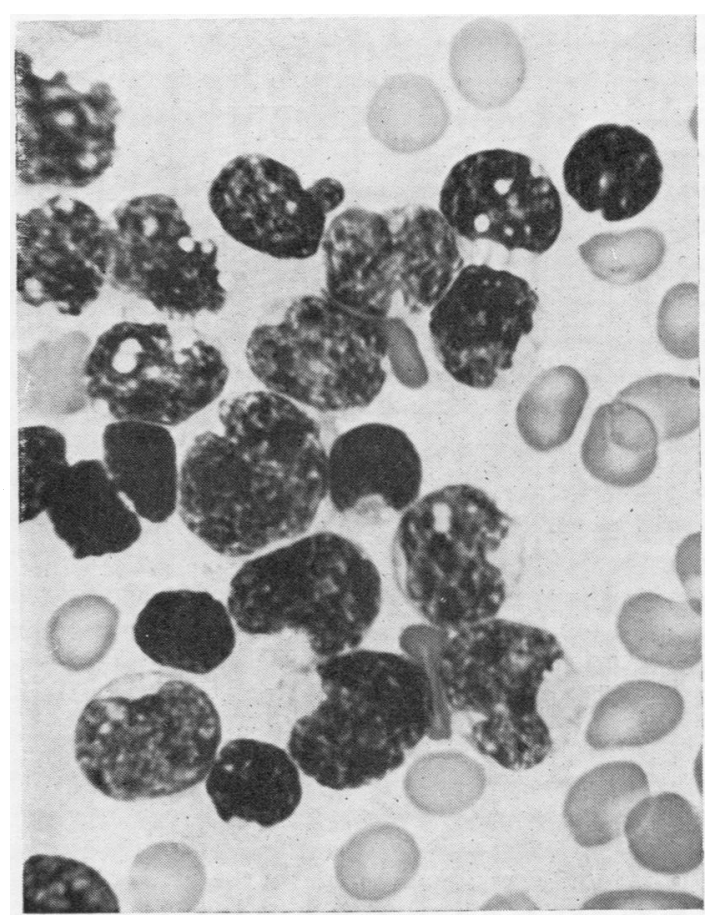

FIG. $4 b$. - Same case as $4 a$, but blood mixed with bovine albumin and centrifuged. Buffy coat film. Leishman, $\times 1,900$.

\section{REFERENCES}

Jeanneret, H. (1940). Schweiz. med. Wschr., 70, 351.

Leitner, S. J. (1949). Bone Marrow Biopsy. Churchill, London. Rohr, K., and Hafter, E. (1937). Folia haemat. (Lpz.), 58, 38.

\section{POSTGRADUATE COURSES IN PATHOLOGY ARRANGED BY THE ASSOCIATION OF CLINICAL PATHOLOGISTS, 1957}

\begin{tabular}{|c|c|c|c|c|}
\hline \multicolumn{2}{|r|}{ Date } & Subject & Institution & For further particulars apply to :- \\
\hline Jan. & $4 \& 5$ & $\begin{array}{l}\text { Pathology of } \\
\text { Diseases of the Skin }\end{array}$ & $\begin{array}{l}\text { Institute of Dermatology and St. John's } \\
\text { Hospital for Diseases of the Skin }\end{array}$ & $\begin{array}{l}\text { Dr. John Oliver, St. John's Hospital for } \\
\text { Diseases of the Skin, Lisle Street, Leicester } \\
\text { Square, London, W.C.2. }\end{array}$ \\
\hline Jan. & $18 \& 19$ & $\begin{array}{l}\text { Pathology of Diseases } \\
\text { of Bones and Joints }\end{array}$ & $\begin{array}{l}\text { Institute of Orthopaedics and Royal } \\
\text { National Orthopaedic Hospital }\end{array}$ & $\begin{array}{l}\text { The Dean, Institute of Orthopaedics, } \\
\text { Royal National Orthopaedic Hospital, } \\
234 \text { Great Portland Street, W.1. }\end{array}$ \\
\hline Jan. & $27 \& 28$ & $\begin{array}{l}\text { Obstetrical and } \\
\text { Gynaecological Pathology }\end{array}$ & $\begin{array}{l}\text { Institute of Obstetrics and Gynaecology in } \\
\text { association with the Chelsea Hospital for } \\
\text { Women and Queen Charlotte's Hospital }\end{array}$ & $\begin{array}{l}\text { The Secretary, Institute of Obstetrics and } \\
\text { Gynaecology, The Chelsea Hospital for } \\
\text { Women, Dovehouse Street, S.W.3. }\end{array}$ \\
\hline Feb. & $8 \& 9$ & $\begin{array}{l}\text { Pathology of } \\
\text { Diseases of Children }\end{array}$ & $\begin{array}{l}\text { Institute of Child Health and Hospital for } \\
\text { Sick Children }\end{array}$ & $\begin{array}{l}\text { Dr. Martin Bodian, The Hospital for Sick } \\
\text { Children, Great Ormond Street, London, } \\
\text { W.C.1. }\end{array}$ \\
\hline Feb. & $22 \& 23$ & $\begin{array}{l}\text { Pathology of Diseases of the } \\
\text { Ear, Nose and Throat }\end{array}$ & Institute of Laryngology and Otology & $\begin{array}{l}\text { Dr. I. Friedman, Institute of Laryngology } \\
\text { and Otology, 330/332 Gray's Inn Road, } \\
\text { London, W.C.1. }\end{array}$ \\
\hline Mar. & $8 \& 9$ & $\begin{array}{l}\text { Pathology of Diseases } \\
\text { of the Nervous System }\end{array}$ & $\begin{array}{l}\text { Institute of Neurology in association with } \\
\text { the National Hospital, Queen Square, and } \\
\text { the Maida Vale Hospital }\end{array}$ & $\begin{array}{l}\text { Dr. John Cumings, The National Hospital } \\
\text { for Nervous Diseases, Queen Square, } \\
\text { London, W.C.1. }\end{array}$ \\
\hline
\end{tabular}

Note: These " week-end " courses in pathology are intended primarily for trained pathologists of consultant or S.H.M.O. status. In exceptional circumstances pathologists of senior registrar grade or other doctors may be accepted, but only if there are vacancies Since accommodation is limited early application is desirable. No fee will be charged, but for most courses there will be a small charge to cover expenses. 